\title{
STATIC AND DYNAMIC LOADS ON THE BOTTOM ROW OF ARMOUR UNITS: A THEORETICAL AND PHYSICAL MODEL STUDY
}

\author{
M.A. van de Koppel $^{1}$ M. Muilwijk² H.J. Verhagen ${ }^{3}$
}

\begin{abstract}
A physical model study on the row averaged static and dynamic load on the bottom row of single layer armour units in order to investigate the influence of various parameters such as the number of rows on the slope of a breakwater and the initial relative packing density.
\end{abstract}

Keywords: rubble-mound breakwater; static load; dynamic load; bottom row;

\section{INTRODUCTION}

Interlocking, single layer concrete armour units are placed on a staggered grid which dimensions depend on the type of armour unit. This implies that armour units are commonly placed in horizontal rows. The number of horizontal rows on a breakwater is limited to 20 . This limit is proposed in order to prevent major settlements, which might affect the interlocking of the armour units. The limit on the number of rows is based on experience from prototypes and is not yet confirmed in a systematic study. The number of rows might also have an effect on the load on the armour units of the bottom row, which is exerted on these units by other units further upslope. This load may affect the structural integrity of the armour units. The load exerted on the armour units of the bottom row has not been addressed in earlier studies.

Earlier research on the structural integrity of concrete armour units was performed amongst others by (Burcharth, 1993). He categorized the loads on an armour units into different load types including a static load and a dynamic load (table 1). In this study the row-averaged static load and the row-averaged wave load (wave related part of the dynamic load) on the entire bottom row of armour units is investigated. The static load is defined as the load on the bottom row of armour units resulting from armour units further upslope if there is no wave action. The wave load is defined as the load on the bottom row of armour units that is caused by waves and is derived from the difference of total load during wave attack (i.e. wave load plus static load) and static load.

The objective of this study is to quantify the static load and the wave load on the bottom row of armour units and to investigate the influence of the total number of rows and of other parameters on these loads.

\begin{tabular}{|c|c|}
\hline Types of load & Origin of load \\
\hline Static & $\begin{array}{l}\text { - Weight of units } \\
\text { - Pre-stressing of units due to wedge effect and } \\
\text { arching caused by movement under dynamic loads }\end{array}$ \\
\hline \multirow[t]{2}{*}{ Dynamic } & $\begin{array}{l}\text { Pulsating: } \\
\text { - Gradually varying wave forces } \\
\text { - Earthquake }\end{array}$ \\
\hline & $\begin{array}{l}\text { Impact: } \\
\text { - Collision between units when rocking or rolling, } \\
\text { collision with underlayer or other structural parts } \\
\text { - Missiles of broken units } \\
\text { - Collision during handling, transport and placing } \\
\text { - High-frequency wave slamming }\end{array}$ \\
\hline Abrasion & - Impacts of sand, shingle etc. in suspension \\
\hline Thermal & $\begin{array}{l}\text { - Temperature differences during the hardening } \\
\text { process after casting } \\
\text { - Freeze and thaw }\end{array}$ \\
\hline Chemical & $\begin{array}{l}\text { - Alkali-silica and sulphate reactions etc. } \\
\text { - Corrosion of steel reinforcement }\end{array}$ \\
\hline
\end{tabular}

\footnotetext{
${ }^{1}$ Delta Marine Consultants, P.O. Box 268, Gouda, 2800 AG, The Netherlands

2 Delta Marine Consultants, P.O. Box 268, Gouda, 2800 AG, The Netherlands

${ }^{3}$ Department of Hydraulic Engineering, Delft University of Technology, PO-box 5048, Delft, 2600 GA, The Netherlands
} 


\section{EXPERIMENTAL SET-UP}

The loads were investigated physical model tests; different types of tests were performed for analysing static loads and wave loads.

\section{Static Load Tests}

The static load was studied in the dry. A test slope was built and the static load on the first row of armour units (in slope-parallel direction) was continuously measured as function of the number of rows on the test slope. The influence of waves and the influence of buoyancy were excluded from this experiment. The static load experiment was executed on a test slope of 37 degrees (3:4) on which an underlayer and an armour layer were built. The bottom row of armour units was placed against a beam, which was supported by suspension that transferred the load on the beam to force gauges (range 0 $1000 \mathrm{~N}$, resolution 1N). This test set up allowed the measurement of forces imposed on the beam (and thus on the bottom row of armour units) in slope-parallel direction by the armour layer.

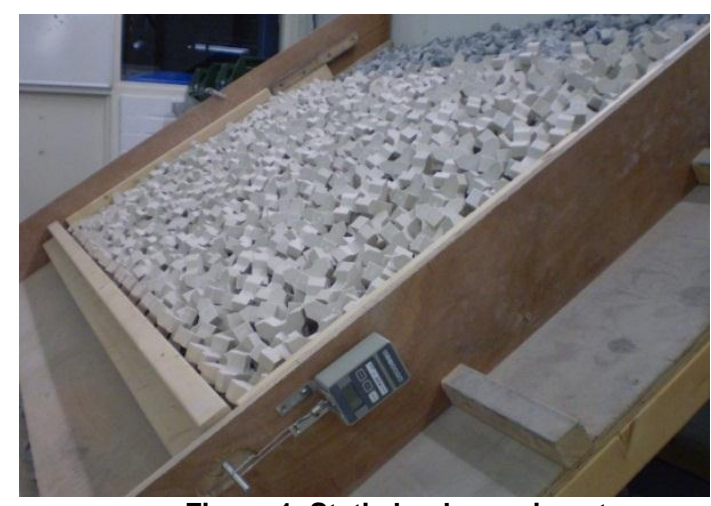

Figure 1. Static load experiment

The armour layer consisted of Xbloc single layer concrete armour units with a unit height of $7.9 \mathrm{~cm}$ and a weight of $366 \mathrm{~g}$. The armour units were placed in a staggered grid. This grid contains 20 armour units per row $\left(\mathrm{N}_{\mathrm{x}}\right)$. A total of 20 horizontal rows were placed on the test slope during each test. The underlayer was made of stones with a standard grading which had a $\mathrm{W}_{50}$ of $36.6 \mathrm{~g}$ corresponded to the requirements for Xbloc underlayers (Delta Marine Consultants, 2011).

The static force was measured during the construction of the armour layer and recorded after the completion of each row. In this way a data set of static loads as function of the number of rows was obtained. This procedure was repeated 15 times. Five of these test were executed with an armour layer constructed with a relative packing density (RPD) of $98 \%$ or less, five of these test were executed with a RPD of between $98 \%$ and $102 \%$ and five test were executed with a RPD of more than $102 \%$.

A second static experiment was executed in order to study the load transfer between armour layer and underlayer on the slope of a breakwater. An armour unit was placed on a tiltable slope of underlayer material (figure 2). Then the slope was tilted until a critical angle was reached and the armour unit started to move in downslope direction(figure 3). At this point the weight component in slope parallel direction exceeds the friction force between armour unit and under layer. The (maximum) load transfer from the armour layer to the under layer can be derived directly from the critical angle and the armour unit weight.

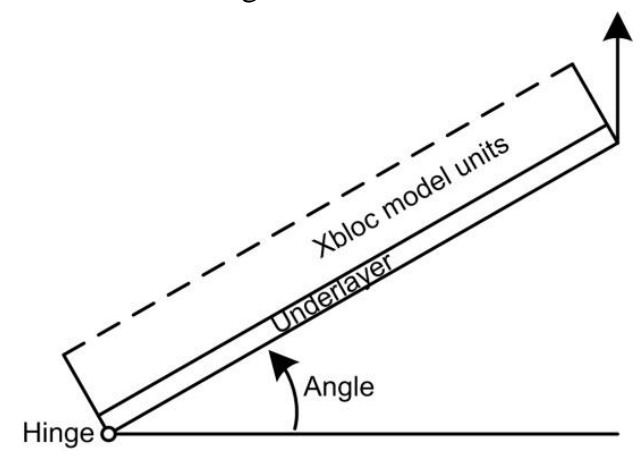

Figure 2. Schematization of individual force balance experiment

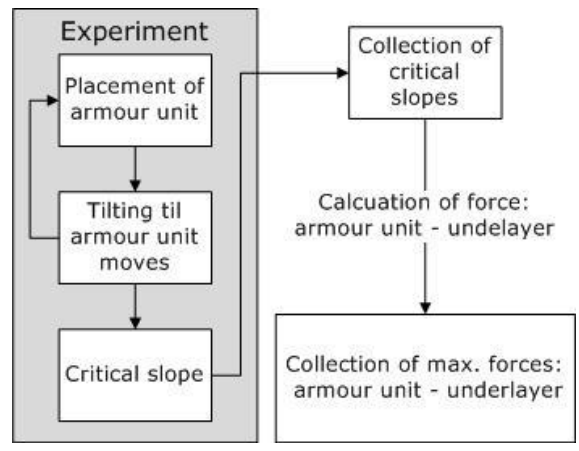

Figure 3. Procedure of individual force balance experiment 
These tests were executed with Xbloc armour units with a weight of $119 \mathrm{~g}$ and a unit height of 5.4 $\mathrm{cm}$. The stones of underlayer corresponded to the requirements for Xbloc underlayers and had a $\mathrm{W}_{50}$ of $11.9 \mathrm{~g}$. The test was executed 200 times.

\section{Wave load experiment}

The wave load was studied in physical model tests in the wave flume of Delta Marine Consultants in Utrecht, The Netherlands. This flume has a length of $25 \mathrm{~m}$, a width of $0.6 \mathrm{~m}$ and a height of $1.0 \mathrm{~m}$. The waves are generated with a piston wave generator which compensated the reflected waves. A breakwater model consisting of a an armour layer of Xbloc armour units with a unit height of $4.3 \mathrm{~cm}$ and a mass of $62 \mathrm{~g}$, an underlayer with a $\mathrm{W}_{50}$ of $6.2 \mathrm{~g}$ and a core with a $\mathrm{W}_{50}$ of $1.9 \mathrm{~g}$, was constructed in the flume.

The bottom row of armour units of the model breakwater was supported by a beam, which was connected to a stiff frame. This frame transferred the loads on the bottom row of armour units to a force sensor, which measured the total load (i.e. the wave load and the static load) on the armour units of the bottom row.

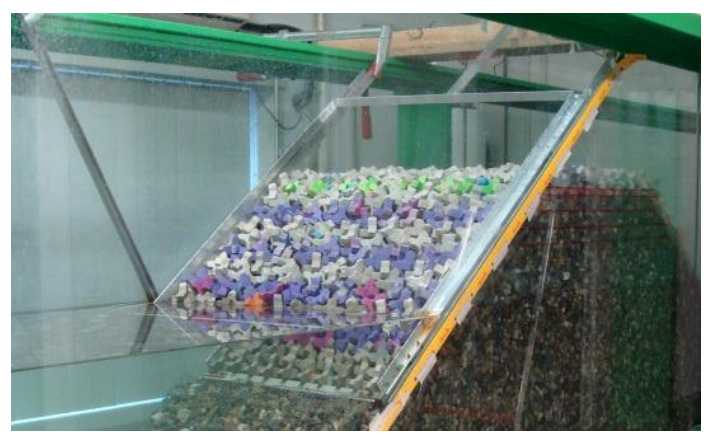

Figure 4. Wave load experiment

The wave load was measured during tests with regular waves varying from $40 \%$ to $200 \%$ of the design wave height of the Xbloc armour units and with a wave period corresponding to an Iribarren number of 3, 4 or 5 for each wave height tested. Several test parameters were varied as specified in table 2. The variation of parameters resulted in a total of 10 tests, each with a unique combination of parameters. Each test was repeated three times creating a test series. The foreshore was flat in all cases. The different tests series were compared to a reference test series. The reference test series are tests with a breakwater model with a slope of 3:4, a total of 20 rows with a RPD of 100\% and a permeable core and a typical underlayer. All parameters were changed one by one as compared to the reference test series.

\begin{tabular}{|l|l|}
\hline \multicolumn{2}{|l|}{ Table 2. Varied parameters in wave load experiment } \\
\hline Parameter & Variation \\
\hline Number of rows & $15 / 20 / 25$ rows \\
\hline Relative Packing Density (RPD) & $97 \%, 100 \%, 104 \%$ \\
\hline Core & Permeable / impermeable \\
\hline Underlayer & Rough \& permeable / Smooth \& impermeable \\
\hline Breakwater slope & $3: 4,2: 3$ \\
\hline
\end{tabular}




\section{ANALYSIS RESULTS STATIC LOAD}

The output of the static load experiment is given in figure 5. This figure show a relation between the number of rows applied on the slope of a breakwater and the load imposed on the bottom row of armour units which approaches an equilibrium of $1.05 \mathrm{~F}_{\text {unit }}$ per unit (average value, $\mathrm{F}_{\text {unit }}$ refers to the dry weight of an armour unit) on the bottom row (+/- 25\%) after about 10 rows.

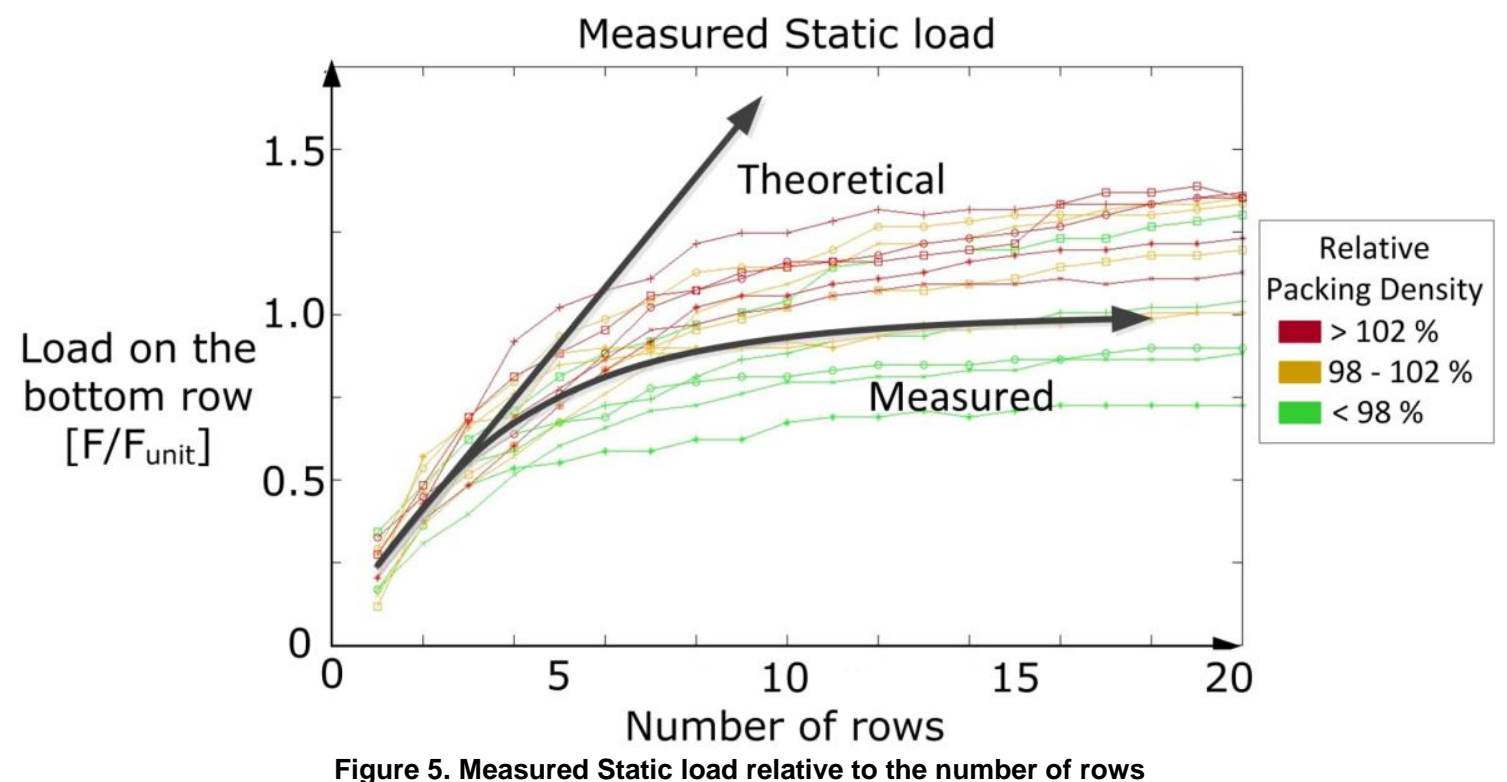

The background of this equilibrium load was further investigated based on the results of the second static load experiment. This experiments provided information on a typical critical slope angle (average critical angle $=38$ degrees) and a typical variation of this slope angle (standard deviation $=8.2$ ). The variation of critical angles indicated that some armour units are fully supported by armour units of the next lower row (i.e. the forces are completely transferred to these armour units), while others are fully supported by the underlayer (i.e. no load transfer to armour units of the next lower row).

This variation in load transfer to the under layer can explain the observed equilibrium in the static load experiment. If the total number of rows is relatively small (say $1-5$ rows) then load on the bottom row is increasing linearly with the number of rows, as a certain part of the load can be transferred directly to the bottom row. When the number of armour unit rows increases, the load on the bottom row approaches an equilibrium, as it becomes more and more unlikely that loads from armour units in the top rows can be transferred directly down to the bottom row.

Based on the results of the static experiment as presented in figure 5 it can be concluded that the influence of armour units placed in row ten or higher have a limited effect on the static load on the bottom row of armour units. The static load on the armour units of the first row will be most probably less than 1.4 times the armour unit weight. 


\section{ANALYSIS RESULTS WAVE LOAD}

A record of one of the wave load experiments is shown in figure 6. The measured wave load was decomposed in a mean load and a peak load. The mean load refers to a wave average load and the peak load refers to the maximum deviation of the actual load from the wave averaged load during a single wave.

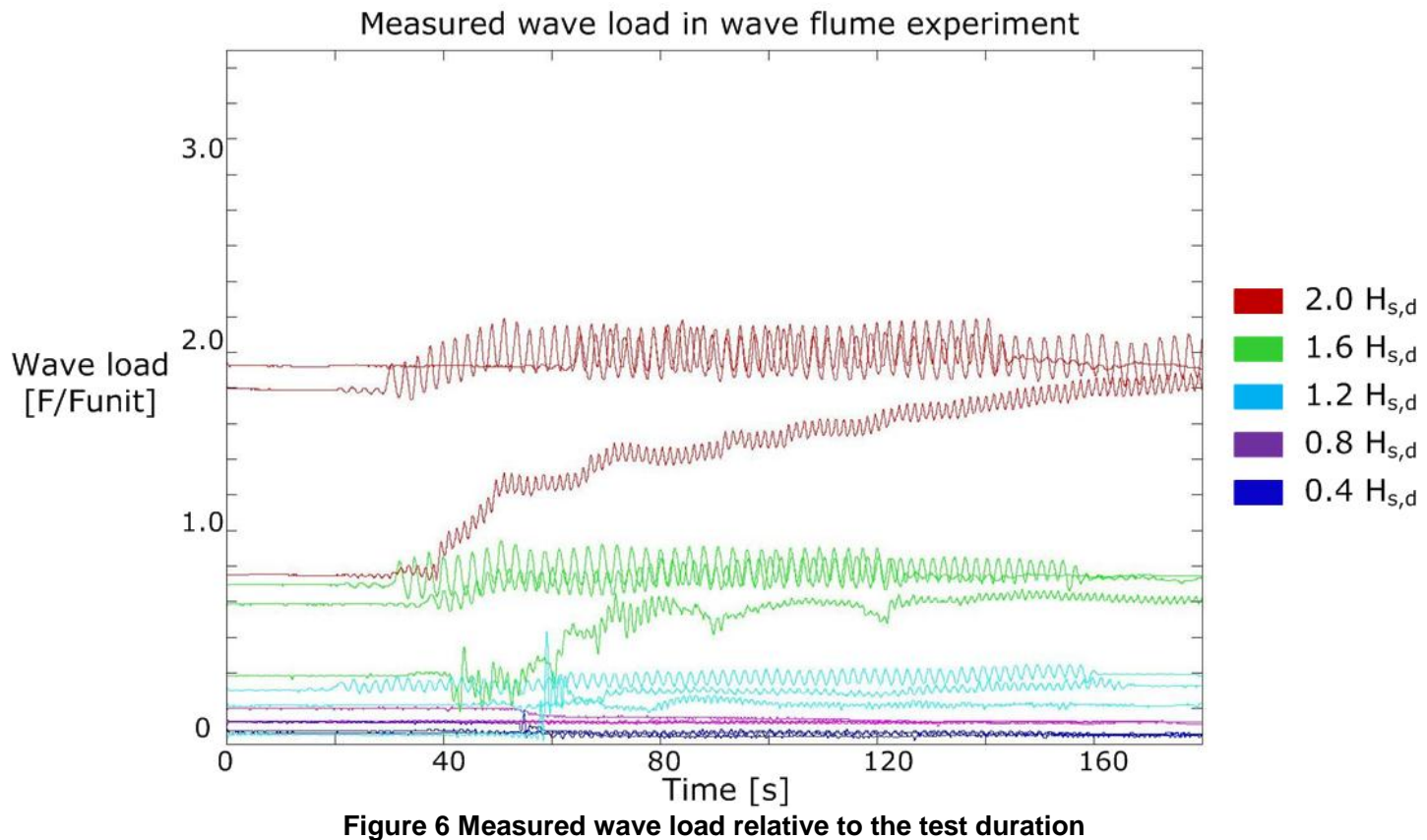

The wave load was found to be a harmonic load with the same period as the waves. The peak wave load on the first row of armour units occurred simultaneous with the maximum downwash. The measured peak load and mean load are plotted in Figure 7 and Figure 8 against the wave height:

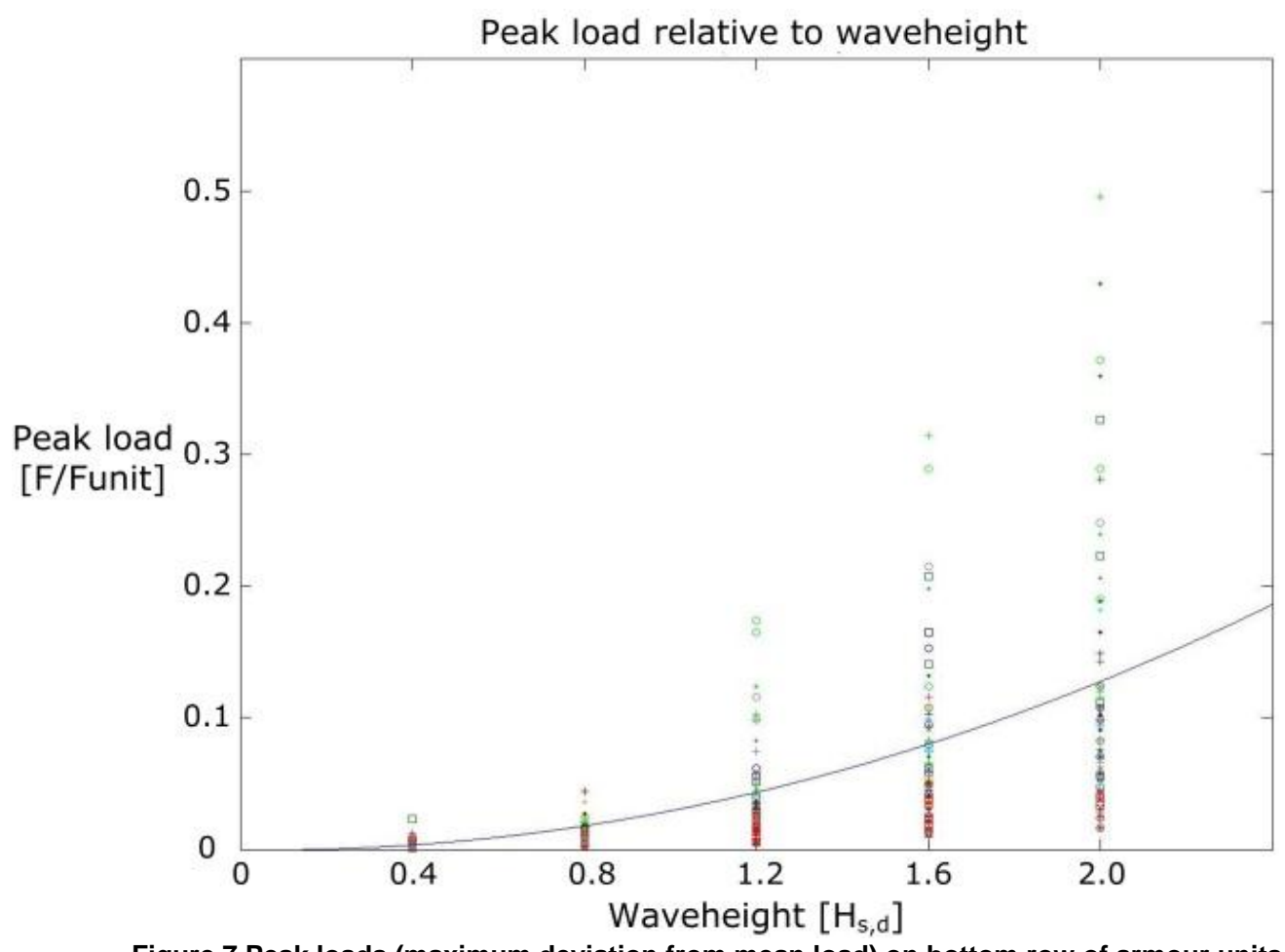

Figure 7 Peak loads (maximum deviation from mean load) on bottom row of armour units 


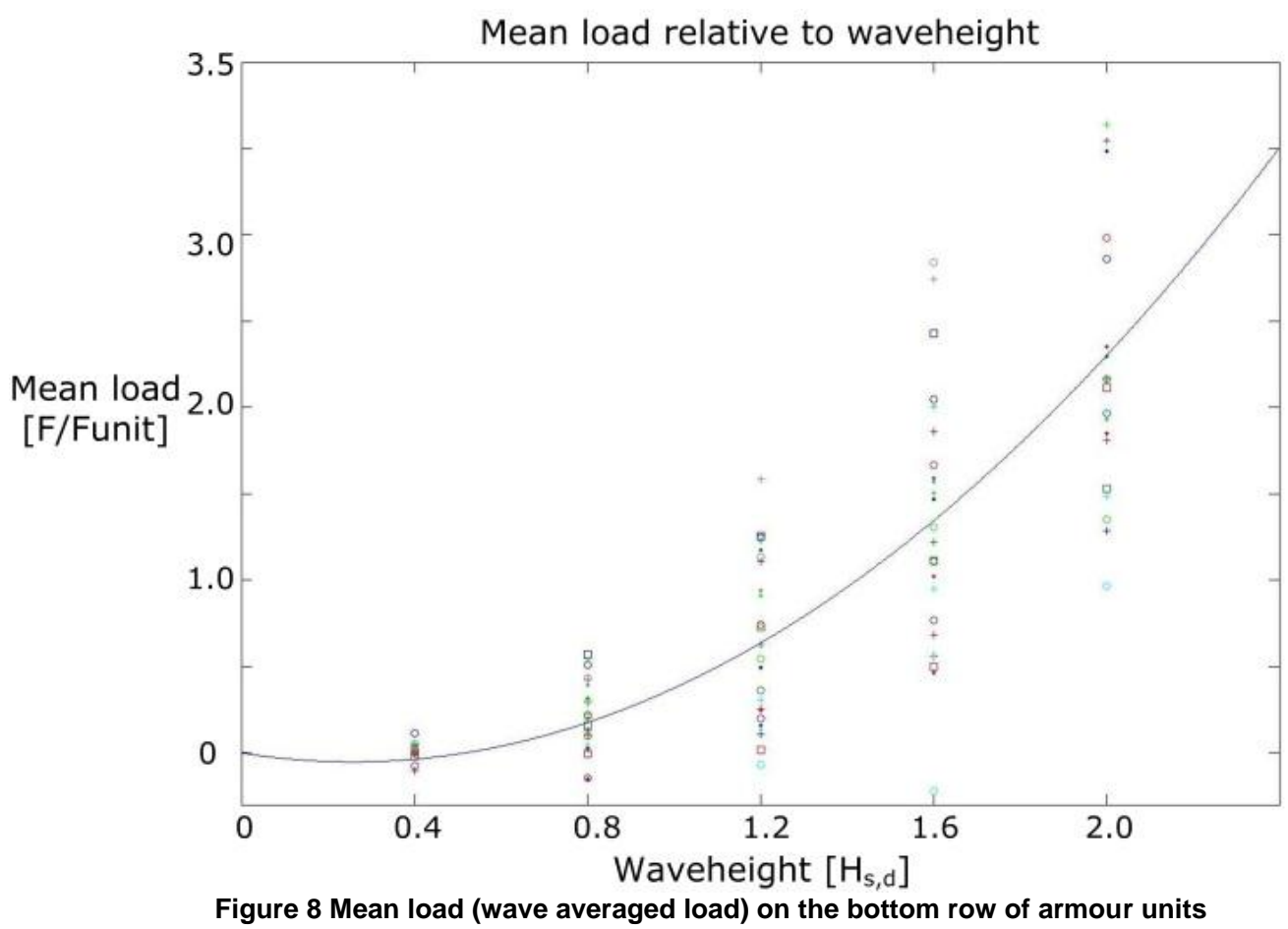

All results from the wave flume tests are presented in Fig 7 and 8. The peak load and the mean load both increase with the wave height. The measured load after testing was typically higher than the measured load at the start of the tests. The scatter of the data around the trend line is significant and can only partly be explained by the influence of the varied parameters. The data per test (with a fixed combination of parameters) can be approximated by empirical functions, which are given in table 3 . The trend lines per test show still a considerable scatter as is illustrated by the norm for residuals.

\begin{tabular}{|c|c|c|c|c|c|c|}
\hline \multirow[t]{4}{*}{ Test series } & \multicolumn{3}{|c|}{ Trend Peak Load } & \multicolumn{3}{|c|}{ Trend Mean Load } \\
\hline & \multicolumn{2}{|c|}{$F_{\text {peak }}$} & \multirow{2}{*}{$+b\left(\frac{H}{H_{s,}}\right.$} & $F_{\text {mea }}$ & \multirow{2}{*}{$\frac{H}{H_{s, d}}$} & \multirow{2}{*}{$+b\left(\frac{H}{H_{s, d}}\right.$} \\
\hline & $\overline{F_{\text {unit }}}$ & & & $F_{\text {unit }} \cdot$ & & \\
\hline & a & b & $\begin{array}{l}\text { Norm of } \\
\text { residuals }\end{array}$ & $a$ & $\mathrm{~b}$ & $\begin{array}{l}\text { Norm of } \\
\text { residuals }\end{array}$ \\
\hline 15 rows, $\mathrm{RPD}=100 \%$ & 0.06 & -0.04 & 0.245 & 0.75 & -1.1 & 1.337 \\
\hline 20 rows, $\mathrm{RPD}=100 \%$ & 0.06 & 0.01 & 0.428 & 0.75 & -0.43 & 2.400 \\
\hline 20 rows, $\mathrm{RPD}=104 \%$ & 0.05 & $-0,03$ & 0.286 & 0.63 & -1.2 & 1.308 \\
\hline 20 rows, $\mathrm{RPD}=97 \%$ & 0.16 & $-0,04$ & 0.953 & 0.58 & -0.30 & 0.954 \\
\hline $\begin{array}{l}20 \text { rows, } \mathrm{RPD}=100 \% \text {, } \\
\text { continuous }\end{array}$ & 0.12 & $-0,05$ & 1.049 & 0.58 & -0.08 & 1.848 \\
\hline $\begin{array}{l}20 \text { rows, } \mathrm{RPD}=100 \% \text {, } \\
\text { impermeable core }\end{array}$ & 0.03 & 0.02 & 0.166 & 3.3 & -0.74 & 2.358 \\
\hline $\begin{array}{l}20 \text { rows, } \mathrm{RPD}=100 \% \text {, } \\
\text { impermeable core, } \\
\text { smooth underlayer }\end{array}$ & 0.02 & 0.03 & 0.219 & 0.03 & 6.1 & 2.570 \\
\hline 25 rows, $\mathrm{RPD}=100 \%$, & 0.02 & 0.01 & 0.131 & 0.95 & -1.57 & 1.498 \\
\hline $\begin{array}{l}20 \text { rows, } \mathrm{RPD}=100 \% \text {, } \\
\text { slope } 2: 3\end{array}$ & 0.05 & 0.03 & 0.613 & 1.15 & -0.74 & 1.334 \\
\hline
\end{tabular}

Based on the comparison of the test series with each other and the reference test series (20 rows, RPD $=100 \%$ ) it was concluded that the permeability of the core, the smoothness of the underlayer and the steepness of the breakwater slope have an influence on both the peak load as the mean load. I is remarkable that an increase of the peak load corresponds to a decrease of the mean load. The number of rows showed no clear influence on both the peak load and the mean load. It was found that external loads imposed on row ten or higher have a limited influence on the load on the first row of armour units. The wave load on an armour unit can be regarded as an external load; wave loads on armour units 
in row ten or higher have a limited effect on the load on the first row of armour units. The influence of the initial RPD on the peak and mean load on the first row of armour units remains unclear. Table 4 gives an overview of the measured variation of peak and mean load due to different test conditions.

\begin{tabular}{|l|l|l|}
\hline \multicolumn{2}{|l|}{ Table 4 Influence of the varied parameters on the peak and mean load } \\
\hline Parameter & Peak Load & Mean Load \\
\hline Normal (20 rows, RPD 100\%) & Average: $0.15 \mathrm{~F} / \mathrm{F}_{\text {unit }}$ & Average: $2.2 \mathrm{~F} / \mathrm{F}_{\text {unit }}$ \\
\hline Impermeable core & Smaller $(-50 \%)$ & Large increase $(+260 \%)$ \\
\hline Smooth, impermeable underlayer & Smaller $(-75 \%)$ & Large increase $(+185 \%)$ \\
\hline Flatter slope (3:4 to 2:3) & Smaller $(-16 \%)$ & Increase $(+75 \%)$ \\
\hline Number of rows & No clear influence & No clear influence \\
\hline Initial RPD & No clear influence & No clear influence \\
\hline
\end{tabular}

\section{CONCLUSIONS}

The static and the wave load on the bottom row of armour units have been investigated. It was found that the static load combined with the mean load are the governing loads on the bottom row of armour units. The static load is a function of the number of rows and reaches a constant value after about 10 rows. The magnitude of the wave load depends largely on the wave height but did not show a dependency on the number of rows or by the packing density. The peak load occurs at the downwash and is also related to the wave height. However, peak loads are significantly smaller than mean loads.

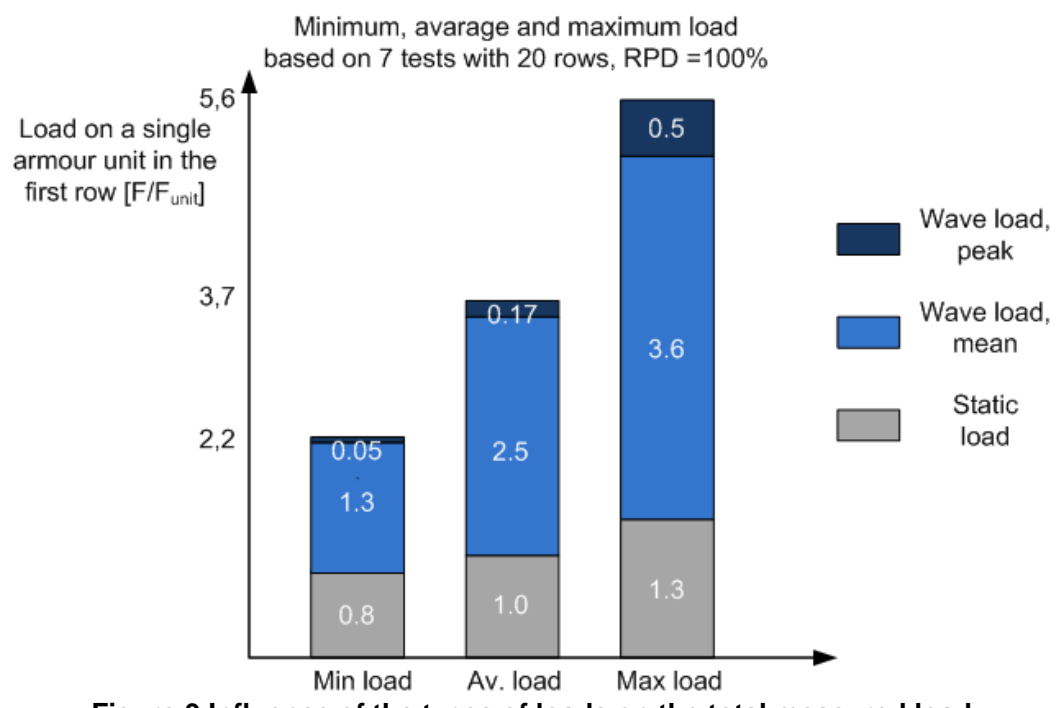

Figure 9 Influence of the types of loads on the total measured load

Total loads (wave load and static load) on armour units of the first row are presented in figure 9. The wave loads refer to the reference case (typical rubble mound breakwater). It can be seen that the contribution of static load, mean wave load and peak wave load are about 30\%, 60\% and 10\%, respectively. It can be further be seen that the load on the armour units in the first row are typically about 3.7 times the unit weight in a design storm and may reach 5.6 times the unit weight. The latter refers to the upper limit of measured loads in this experiments.

\section{REFERENCES}

Burcharth, H.F. 1993. Structural Integrity and Hydraulic Stability of Dolos Armour layers. Series paper 9 Hydraulics \& Coastal Engineering Laboratory, Aalborg University, Aalborg, Denmark

Delta Marine Consultants (2011) Guidelines for Xbloc Concept Designs. Brochure Delta Marine consultants (available at xbloc.com), Gouda, The Netherlands 